\title{
Technological Risks of the Digital Economy
}

\author{
Mikhail Chernyakov \\ Doctor of Economics, Professor \\ Professor of audit, accounting and Finance Department \\ Novosibirsk State Technical University \\ 20 Karl Marx Ave., Novosibirsk, Russia \\ E-mail: mkacadem@mail.ru
}

\section{Maria Chernyakova}

Candidate of Economic Sciences, associate Professor Associate Professor of Management Siberian Institute of Management 6 Nizhniy Novgorod St., Novosibirsk, Russia

E-mail:mariamix@mail.ru

\begin{abstract}
This article postulates that the successful development of the digital economy will be ensured by strengthening the position of corporations, increasing quality of corporate governance, and increasing the interaction and clarity of the structure of financial institutions in accordance with the latest technologies. A general definition of the term 'digital economy' is formulated to understand this transformation. The digital economy (as an environment) includes a combination of digital infrastructure, innodiversification information, and communication technologies for doing business. This article discusses issues related to the development of new methods of risk assessment and their impact on business processes in the formation and development of the digital economy.

The article further emphasises that corporations must pay special attention to the risks inherent in the digital economy in the transformation process. The purpose of this study is to identify the most significant risks. The study was conducted through hierarchical methods for developing classifications, ranking, and a priori analysis. It has been established that the highest priority of research in the traditional economy is given to financial and commercial types of risk as a result of an a priori analysis. A classification of risks of the digital economy is herein proposed.

The article further states that the most specific corporate risk for the digital economy is a specific risk, called technological risk. The concept of technological risk is suggested in order to understand the problems associated with large-scale acceleration of the digital economy, and the development and implementation of information and communication technologies. The development of these technologies appear almost impossible to halt due to their tending toward self-propagation and interactive innovation. The article highlights the positive trend of the emergence of an innovative financial system, which is based on digital platforms, technology and marketing. A well-thought and concerted strategy of digital transformation is important for corporations and successful businesses in modern conditions, instead of disparate use of separate tools.

The article also notes that the contradictions in strategy and influence between the leading transnational corporations are becoming one of the main sources of risk in the new conditions of the digital economy from the point of view of ensuring national security issues.
\end{abstract}

Keywords: digital economy, corporate risks, digital economy risks, financial risks, technological risks, management, risk management, corporate governance, corporate governance principles

JEL: G32, G34, G38 


\section{Introduction:}

\section{the digital economy}

The successful development of the digital economy will be ensured by strengthening the position of corporations, increasing the quality of corporate governance principles, and increasing the interaction and clarity of the relevant structure of financial institutions. These changes are much more serious than the initial changes in the field of information and communication technologies (ICT) which contributed to the development of the digital economy. Changes have taken place in every sector of the market: competitive structures, consumer preferences, purchasing habits, marketing and advertising strategies, production operations, internal management systems, supply chain mechanisms and the opening up of the global economy. Managers assume that the uncertainty and risks associated with the management of their businesses increase as a result of such changes. The key to survival in the digital economy lies in the ability of managers to effectively use ICT to manage these uncertainties and risks [1].

The digital economy (table 1) is referred to as the economy based on digital computing technologies. It is sometimes referred to as the virtual, networked, electronic, new, internet, or web economy. There is no clear distinction between the digital and traditional economies, they are closely intertwined.

Table 1. Definitions of the digital economy

Definitions

Electronic economy (digital, web, internet economy) - "economic activities based on digital technologies related to e-business and e-commerce, and produced and sold by them electronic goods and services"

\section{Source}

Wikipedia: https://ru.wikipedia.org/ wiki/ E-economy

Network economy (virtual, digital, electronic) - "economic activities carried out with the help of electronic networks (digital telecommunications). Technologically, the network economy is an environment in which legal entities and individuals can communicate with each other about joint activities"

"The digital economy is an economic activity in which data in digital form, processing of large volumes and the use of analysis results are key factors of production. They can improve the efficiency of various types of production, technology, equipment, storage, sale, delivery of goods and services (compared to traditional forms of management)"

Glossary.ru: Network economy. http://www.glossary.ru/cgi-bin/ gl_sch2.cgi?RRlylig9!_qutusoqg

The strategy of information society development in Russian Federation to $2017-2030$. The decree of the President of the Russian Federation from 09.05.2017, No. 203. http:// kremlin.ru/acts/bank/41919

"Digital economy is an activity directly related to the development of digital computer technology. It includes: online services, electronic payments, online trading, crowdfunding, etc."

http://www.fingramota.org/teoriyafinansov/item/2198-chto-takoetsifrovaya-ekonomika

"Digital economy - a system of economic, social and cultural relations based on the use of digital information and communication technologies"

http://www.tadviser.ru/index. php

/ Article\% 3A Digital Economy of Russia

"The digital economy is a global network of economic activities, commercial transactions and professional interactions that are provided by information and communication technologies (ICT)"

http://www.tpinauka.ru/2018/02/ Skripko.pdf

The influence of digital technologies on the change of socio-economic systems is readily evident, however, most of the consequential issues remain poorly studied [2]. Very little attention is paid to the impact of risk on the development of digital potential, which can contribute to the innovative growth of corporations.

The problems of business development in the context of the digital economy are poorly described. Also, the emergence of new risks specific to the digital economy are not reflected in the overall system of modern economic relations. Thus, the aim of this work is to study the primary areas of relevance to corporate transforma- tions to the digital economy, especially in consideration of the impact of new risks associated with such transitions.

It is possible to formulate a generalised definition of the term 'digital economy' based on the definitions and concepts outlined below (see table 1). We therefore propose the following definition: 'the digital economy is an environment that includes a set of digital infrastructure and indiverse information and communication technologies for doing business'. The term 'innodiversity' was introduced in 2016 [3], and characterises the penetration of innovations into new sectors. 


\section{The model of the digital economy}

The program 'Digital economy of the Russian Federation' was approved in July 2017. It determines the development of the country's digital economy for the period up to 2024 [4].

The need to adopt this document was caused by the process of 'digitalisation' of the domestic economy, as well as the desire to speed up those processes and give them a certain order.

Proper implementation of the digital economy development program necessitates the approval by the government once every three years of an operational plan with regular updating of the list of activities presented in the program. The program 'Digital Economy of the Russian Federation' is focussed on the fact that data presented in digital form is a key factor of production in the digital economy [4]. These data represent a new resource base, analysis of which allows one to make more effective decisions in various fields of production, as well as in various areas of the national economy. A prerequisite information space' has been formed, taking into account the needs of citizens and society in obtaining high-quality and reliable information, and the 'information structure' is developing, as Russian information and telecommunication technologies are developing. Finally, a new technological base of the socio-economic sphere is being formed - and all this is due to the digital economy [2].

The digital economy model presented in the program includes three closely interacting levels, they are shown in figure 1 [5].

Figure 1. Levels of the digital economy model

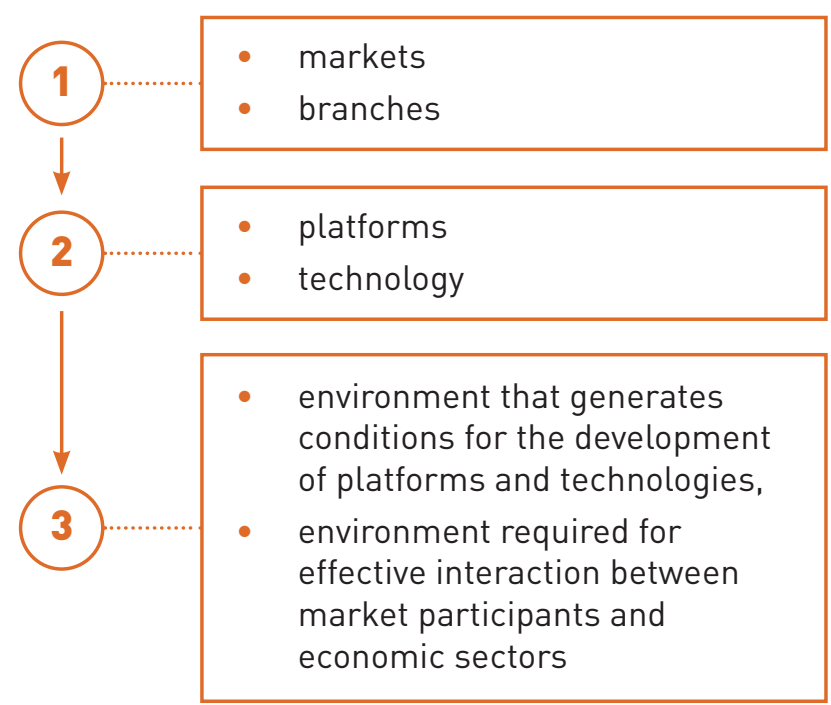

The program 'Digital Economy of the Russian Federation' provides for the priority development of eight main areas that will be in line with development in the coming years [5]:

1) "Smart city";

2) public administration;

3) health;
4) regulation;

5) digital infrastructure;

6) technological innovations;

7) human resources and education;

8) information security.

The practical implementation of the main directions of the program [4] will greatly help to close the distance between Russia and the top ten countries (Singapore, Finland, Sweden, Norway, USA, Netherlands, Switzerland, Great Britain, Luxembourg and Japan) in the use of digital technologies. The intensification of the process of using digital technologies in Russia may become one of the essential factors for increasing the level of competitiveness of the domestic economy, which ultimately will contribute to the growth of the well-being of the Russian people.

\section{Research methods}

A business analytics investigation is needed to explore the basic capabilities, constraints, problems and risks of the digital economy [6]. Hierarchical methods for developing classifications, and an a priori analysis and ranking were applied as the main research methodologies in this paper. Three groups of methods for the classification of objects are used most widely in the initial practice: hierarchical, faceted, and descriptor. Hierarchical methods were chosen as the main ones in the study (Fig. 2); they are characterised by a sequential algorithm for dividing a given set of objects into subordinate subsets. Subsets form a unified classification system of the distributed set with interconnected divisions, a single whole in which all parts are interconnected and in a certain way are coordinated according to these methods [7].

\section{Classification of risks}

A ranked analysis of the bibliography of domestic and foreign authors was made, and statistical data were collected and processed as a result of studying the possible risks of accelerated development of the digital economy [8]. These activities allowed for the identification and description of the following types of risks:

1) the danger of negative consequences of the formation of a new type of personality - digital nomads;

2) the risk of negative consequences of the formation of the world of imitation information, fake news and its replication by individuals with a reduced reflection level (spontaneous sales, etc.);

3) the genesis of tracking systems, online tracking produced by individual actions with the further development of anonymity systems;

4) the administrative risks of transforming the role of the state and changing the existing legislative system;

5) the risk of accelerating the release of low-and medium-skilled labour if the demand for new ICTs grows faster than the capacity of the education system to train skilled personnel. This leads to increased social tension. 
Therefore, it is important to understand that the issue of promoting additional information in enterprises is not only an economic task, but also a socio-cultural one. It involves working on existing cultural barriers to their gradual elimination. It is important that educational, managerial and technological decisions are subordinated to humanitarian goals, and humanitarian goals are sufficiently correlated with economic tasks when launching a complex socio-cultural process [9].
The process of forming the risk classification of the digital economy began with the analysis of risk classifications of the traditional economy. The most popular system of such classification is shown in figure 3. It follows from this that the highest priority in the analysis is given to financial types of risk, as well as commercial risk (highlighted in green), while average priority is given to production and personnel (highlighted in yellow). Therefore, further research will focus on the financial component.

Figure 2. Hierarchical classification method

\begin{tabular}{|l|l|}
\hline $\begin{array}{l}\text { Rules } \\
\text { of construction }\end{array}$ \\
\hline
\end{tabular}

\section{Advantages}

\section{Disadvantages}

Figure 3. Classification of corporate risks of traditional economy ${ }^{1}$
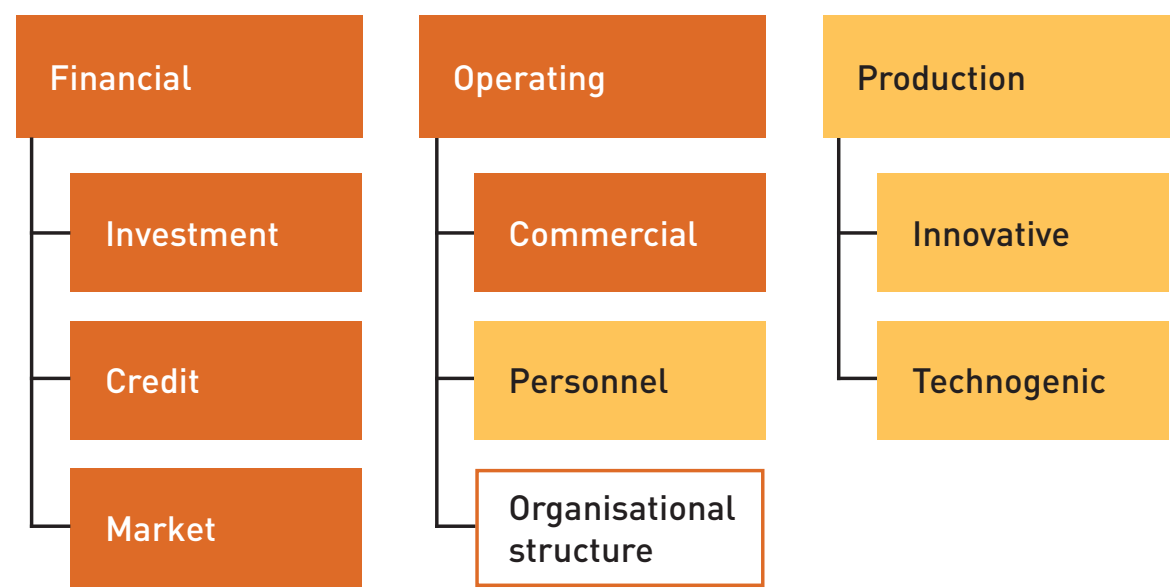

- The division of the set should begin with the most common features.

- Only one feature (which is of fundamental importance for this stage) can be used at each stage.

- It is necessary to establish the optimal number of features, stages and depth of classification.

- The division of facilities should be carried out sequentially from the largest to the smallest, from the general to the particular.

- The possibility of identifying the similarity of signs on the same and different steps.

- High information saturation.

- Visibility.

- Ease of construction.

- High costs to apply.

- Bulkiness (with great depth).

- Information failure and incomplete coverage of objects and signs (with a shallow depth).

- Difficulty of application due to multistage and a large number of interrelated subsets. 


\begin{tabular}{|c|c|c|}
\hline \multirow[b]{3}{*}{ Political } & Country ("digital colonization") & Penetration of foreign IT-technologies in all aspects of life and activity \\
\hline & & Finance, transport and energy infrastructure, economic management, social engineering and modelling \\
\hline & & Database security and knowledge of database components and content \\
\hline & & Investments, start-ups, new money, new industries, renewal of traditional industries \\
\hline & & Capture of the economy by stronger and richer foreign players and introduction of external economic management \\
\hline
\end{tabular}

\begin{tabular}{|c|c|c|}
\hline & Innovation (introduction of new ICT) & The emergence of new viruses and vulnerabilities \\
\hline \multirow[t]{2}{*}{ Economical } & Country ("digital colonization") & Markets, new business models, new large companies, new mass services and information services \\
\hline & Marketing ("Economics of exchange") & Disappearance of intermediaries, increase of speed and standardisation of services, uberisation of medicine, education, transport, services \\
\hline
\end{tabular}

\begin{tabular}{|c|c|c|}
\hline & Job loss & Labour productivity growth \\
\hline \multirow{2}{*}{ Social } & Unemployment & Efficiency gains \\
\hline & Social tension & Introduction of artificial intelligence \\
\hline & The onset of the parasite layer & Automation, robotics \\
\hline
\end{tabular}

\begin{tabular}{|c|c|c|}
\hline & & Big data, personal data analysis, electronic identification and identity authentication, electronic citizen double \\
\hline \multirow{2}{*}{ Psychological } & है⿴囗十⺝ & Disappearance of privacy, intrusive advertising, new digital totalitarianism, leakage of personal data of citizens abroad to powerful foreign players \\
\hline & $\begin{array}{l}\text { Personal (development of } \\
\text { "clip" or machine thinking) }\end{array}$ & Instant, mathematical-linear, visual, fragmentary, high-speed and surface \\
\hline & Fixies & Man, becoming part of the machine, "fixies", becomes $100 \%$ interchangeable with it, like any microchip of the computer \\
\hline
\end{tabular}
Analysis of various sources of information [5-8, 10-13] allowed to develop the author's classification of risks inherent in the digital economy. The classification is shown in figure 4. 


\section{Technological risk}

The paper by Dragan Stojanovic [14] shows the possibility of a significant increase in business efficiency. It was based on the experience gained in the previous business of the corporation and the positive experience of those who successfully solved the new problems of innovation in business and the correct application of new ICTs in the digital economy. Also, there are examples of the use of modern ICT in the transformation of business processes, analysis of trends that can be expected in the future, as well as the risks faced by the corporation.

The analysis of the proposed classification showed that the most specific risk for the digital economy is the risk that we call technological. Under the technological risks category it is proposed to understand the risks associated with large-scale and accelerating processes of the digital economy in the development and implementation of information and communication technologies (it is almost impossible to stop them because of their self-feeding). These risks have a tendency towards self-development like 'mudflow' or 'snow avalanche'.

It is necessary to pay special attention to infrastructure and modern technologies in the activities of corporations (such as modern computers, software, and the availability of qualified specialists) to reduce technological risks.

Also, digital technologies are used to accelerate innovation processes, because this factor is the most competitive in the market [15]. New business models are emerging based on group methods of creation and usage, changes in market relations, and the need to achieve new results in the field of firm management. Changes in these technologies are important for the whole economy.

Authorities in various countries seek to develop the digital economy to address such problematic areas as the unemployment rate, the fight against poverty and others. Innovative digital strategies raise issues of creating modern enterprises, increasing employment, etc. As such, the development of the digital economy is of primary importance in Russia.

The electronics industry creates innovative technologies for the digital sector, which is represented by two elements: the production of chips and the provision of services in the form of digital technologies. The growth of the digital sector for the national economy indicates its importance, so many countries are developing related programs to create jobs and to further develop electronic-based industry and technology now.

As it develops, investment becomes the focal point in the digital sector of the economy. The problems of the digital sector have a strong impact on the competitiveness of economies at the moment. The international dependence of one country on another could widen the gap in economic development due to a kind of technological or innovative bottleneck. The peculiarity of this structure is that the development of digital technologies occurs at the highest speed, and innovative technologies are created on the basis of prior results.

The concepts of nation sovereignty, national security and the independence of Russia in an open market economy, as well as the related issues of the cold and sanctions war against Russia indicate areas of potential vulnerability. Counteractions can consist only in the advancing of an information jump (a development of Russia's own, reliably protected from external influences of the information technologies based on the basic principles of innovation). It is contradictory and extremely difficult to remain in the embrace of it-technologies of the hostile West and to carry out effective protection of sovereignty at the same time.

\section{Country risks}

The threat of country risk lies in the penetration of foreign IT-technologies into all aspects of life and activity. One may use the 'country beta model' to assess country risk. This model suggests that country risk is the ratio between the profitability of the stock market in a particular country and the profitability of the stock market in the rest of the world [7]. The most important point is that country risk is included in the group of political risks most relevant in the context of sanctions and counter sanctions. If economic and financial risk factors are quantifiable, then political factors are difficult and only partly amenable to such analysis. To assess country risks, one may use the rating scales of Russian and foreign agencies [7, 15].

Financial and technological digital platforms (one of them being 3DEXPERIENCE, from the French company Dassault Systèmes operating in the CAD and PLM segment) are gaining great popularity recently, and experts create software for them. Innovative methods transform domestic banking and customer service.

In a business environment, organisations interact with customers and amongst each other. As an example of the latter concept, one may consider the firms which engage in the development of business optimisation technologies. They offer such technologies on more attractive terms and at lower cost than credit institutions. Digitising such processes allows for the optimisation of costs and operations and the increasing of transparency and quality of interaction with customers.

For example, Dassault Systèmes develops and actively implements a competition named 3D FinTech Challenge in its business program. This program helps start-ups to quickly get used to actual market conditions. This alone may have helped to accelerate the introduction of innovation and development of enterprises in the credit industry. The financial crisis of 2007-2009 led to the collapse of the classical banking system in almost all countries of the world. ICT outsiders took advantage of this situation and offered new financial instruments to disillusioned depositors and borrowers - cryptocurrency.

The special feature of cryptocurrency is that they can be bought for real money (dollars, pounds, euros) and 
'mined'. Many people rushed to computers to mine Bitcoins. As of the time of writing, Bitcoin is undoubtedly the most famous cryptocurrency.

People and organisations from the ICT world are revolutionaries in the field of financial technology. They are distinguished by their creativity, aggressiveness and good organisation, which allows them to seize new beachheads and destroy the status quo. They are looking for allies among the authorities. In this regard, it may be noted that the Bitcoin project is a prime example of cooperation between ICT companies and US intelligence agencies.

Bitcoin entered the market in 2009. As it is such a massive project, a single specialist could not have been its deviser. Criminal structures were the first to become interested in new money, as the cryptocurrency provided complete anonymity. Actions to "clean up" the criminal business (that used bitcoins) were held in the United States in 2013. Cryptocurrency was almost legalised in 2015.

Publications in the news media fuel interest in bitcoin. Cryptocurrency is positioned as a means of payment that provides anonymity, privacy and complete transactional freedom. But in fact, US intelligence agencies control the peer-to-peer networks that many Bitcoin enthusiasts use.

Quantum computing will become a reality with the development of technological progress in the near future. State organisations, intelligence agencies and private corporations are spending billions of dollars annually in efforts to develop it. Quantum computers would in theory allow users to crack the cryptographic protection of Bitcoins.

Therefore, some financial companies have developed their own practical settlement money, taking as a basis the technology known as 'blockchain' which underpins the creation of Bitcoin. The digital currency is planned to be used in settlement and clearing operations and transactions with securities without the involvement of intermediaries (i.e. the role currently played by banks). Large credit institutions are joining the system in many countries, which indicates the success of the project. The project is planned to be implemented this year.

Mobile money has a significant impact on the economy of different countries. Mobile banking is particularly developed in sub-Saharan Africa. The infrastructure of this region does not allow the full use of the classical banking system, so more than half of the borrowers use illegal sources of loans. The share of official loans increased by $16 \%$ with the introduction of mobile banking.

For example, the M-Pesa mobile money transaction system works in Kenya. This system works as follows: operators accept cash from users and place it into electronic accounts, and then transfer to recipients via SMS. The funds for 11,000,000,000 dollars were transferred to Kenya through this service in 2014. Also, a similar system is common in Romania and India.

However, mobile currencies are not only used in third world countries. Well-known participants of the financial market of developed countries also use them. For example, the popular companies Circle and Venmo service e-wallets, through which online transfers and payments are made. Also, the well-known company Facebook Pay utilises new financial technologies.

Digital marketing is a system in which statistics, information processing and feedback are important. The user gets more accurate information about the target audience through dashboards, and innovative services help to form individual offers. Various advanced start-ups offer corporations modern digital marketing services with a wide range of innovative features, the most notable of which are listed in table 2 [5].

Table 2. New marketing services

\begin{tabular}{|c|c|}
\hline Service & $\begin{array}{l}\text { Characteristics } \\
\text { of start-up features }\end{array}$ \\
\hline CoMagic & $\begin{array}{l}\text { acts as a data integrator and can be } \\
\text { the client's source for other analytical } \\
\text { platforms; }\end{array}$ \\
\hline $\begin{array}{l}\text { Insight } \\
\text { \& Target }\end{array}$ & $\begin{array}{l}\text { provides financial institutions a per- } \\
\text { sonalised approach to each client; }\end{array}$ \\
\hline Optimove & $\begin{array}{l}\text { is aimed at the launch of test programs } \\
\text { and the creation of micro segments } \\
\text { that allow the client to cover small } \\
\text { groups of potential customers; }\end{array}$ \\
\hline Uniken & $\begin{array}{l}\text { automatically identifies visitors who } \\
\text { appeal the contact center; }\end{array}$ \\
\hline SaleMove & $\begin{array}{l}\text { allows users to stay within a single } \\
\text { toolbar when switching from text- } \\
\text { based chat to audio or video chat; }\end{array}$ \\
\hline Jiffee & $\begin{array}{l}\text { allows clients to use their phone as } \\
\text { a payment terminal, thereby reduc- } \\
\text { ing the cost of purchasing additional } \\
\text { equipment; }\end{array}$ \\
\hline Nanopay & $\begin{array}{l}\text { reduces the risk of cross-border pay- } \\
\text { ments and reduces the cost of money } \\
\text { transfers; }\end{array}$ \\
\hline $\begin{array}{l}\text { Relationship } \\
\text { Planner }\end{array}$ & $\begin{array}{l}\text { mobile e-HR manager which helps to } \\
\text { distribute tasks among employees and } \\
\text { assess their potential; }\end{array}$ \\
\hline Bpm Online & $\begin{array}{l}\text { a service which connects to the work } \\
\text { of senior managers and transfers their } \\
\text { operational profiles to top customers. }\end{array}$ \\
\hline
\end{tabular}

However, it may be postulated that the future belongs to those enterprises that can integrate as many automated services as possible into their work, connecting them to each other without compromising service quality.

The overall financial segment of the world market is changing rapidly. Almost all new technologies in the field of finance are aimed at successful integration into the new reality. Such functions are generally associated with changes in the areas of $\mathrm{B} 2 \mathrm{~B}$ and $\mathrm{B} 2 \mathrm{C}$ payments, levelling obstacles in the process of transition of the industry to 
digital technologies, the creation of new standards of electronic payments, business optimisation, cost reduction through automation, reducing the burden on employees, the use of electronic assistants, and personalisation of goods and works. As referenced earlier in this article, corporations need to employ a well-thought-out strategy to harmonise and coordinate the use of digital information, rather than haphazardly employ individual tools, if they wish to build successful business in modern conditions.

\section{Cybersecurity risks}

The danger of cybersecurity risks is primarily associated with internet-based threats to the digital components of life and business activities, such as finance, transport and energy infrastructure, social engineering and modelling, and economic management,. The rapid growth in the number of cybercrimes, combined with information leaks, has caused significant damage to data and knowledge databases, their components and content. This creates a need for manufacturers to invest in information security. This results in a significant drain on financial resources and a distraction from the main activity of the manufacturer.

Experts have estimated the cost of damage from one single information security incident at the amount of 1.6 million rubles for small and medium-sized businesses, increasing to 11 million rubles for large domestic companies [5]. The national economy is faced with the problem of lack of specialists in information security, which, in the opinion of the author, is an issue the state itself should take responsibility for.

Significant business losses in recent years have been associated with the spread of 'ransomware', which penetrates into a computer and encrypts important information in order to demand a ransom for its restoration. Every fifth company in the world faced at least one similar incident in 2016, according to Kaspersky Lab. At the same time, about $70 \%$ of the victims of such programs lost all or part of their corporate data, and $20 \%$ of the victims spent several weeks trying to restore access to the data. More than $30 \%$ of the attacked companies paid the ransom, but every fifth payer was not able to recover their data after payment. For example, the victims of the most audacious attack of the virus called 'WannaCry' constituted more than 300 thousand computer users in 150 countries in 2017. Among those who fell victim to a virus attack were such major domestic companies as MegaFon, Sberbank, Russian Railways and a number of others.

Some of the threats posed by the digital economy affect the development of the labour market and are linked to the enormous release of workers. The widespread automation of production processes in conjunction with the standardisation of basic operations can successfully replace the work of workers with robotics. This subsequently leads to a significant release of employees of a number of specialties, such as cashiers, operators, clerks, storekeepers, packers, and entry-level accountants. Sberbank is actively implementing the robotisation process and plans to implement robotisation at 100 of its centers in the near future. Currently, a number of technical tasks in Sberbank are performed by robots (for example, the decision to issue loans to individuals). The processes of releasing lowskilled workers are typical within the domestic economy $(174,000$ jobs in the financial sector and 364,000 jobs in trade, car service and household repairs were eliminated in 2016, according to Rosstat).

The impact of the digital economy on the labour market is also manifested in the reduction of remuneration of low-skilled workers. Experts expect a drop in salary offers for low-skilled workers of 5\% from 2018. Specialists of the Boston Consulting Group believe that in the next 10-20 years, as a result of the digital revolution, $50 \%$ of the professions in the world will disappear.

\section{Innodiversification risk}

The danger of an innodiversification risk is estimated by the likelihood of an economy being largely captured by stronger and richer foreign players and the consequent introduction of external management of the economy [3]. This risk is characterised by the emergence of a flood of investments, start-ups, electronic money, new types of industries, and the 'redirection' of traditional industries, all of which influences are significantly focused in foreign countries and greatly affect the client country's economy.

The next technical revolution is likely to occur in the field of finance [5]. The transformation of financial services is associated with the introduction of digital technologies that industrialise processes, reduce costs and automatically ensure compliance with the requirements of regulators. An example of such an innovative financial and technological system is FinTech. Today, the topic and utility of FinTech is widely discussed among representatives of credit institutions and commercial companies in the central banks of some countries and in international economic forums.

New technologies in finance are actively being introduced in the areas of banking, exchange operations, insurance, money transfers, asset management, etc. However, their implementation is associated with certain difficulties. These difficulties are caused by the following factors:

- the need for innovation;

- changing customer requirements;

- growing pressure from regulatory organisations.

However, these difficulties create grounds for healthy competition between the old market participants and start-ups. European and American investors invested $\$ 1,000,000,000$ in 2017 in FinTech enterprises. As a result, credit institutions should increase the quantity and quality of services provided by reducing costs, which will assist new high-tech companies to appear on the market. On the whole, the degrading financial system must improve and acknowledge that the path to progress lies in the technologies described. At present, new technologies are most often used by small and medium-sized businesses, since 
they are more mobile and strategically dextrous.

New technologies in the financial sector include:

- ICT (information and computer technologies);

- crowdfunding (public funding);

- integration with cryptocurrencies;

- transaction transformation;

- the introduction of new services;

- other features.

\section{Criteria for analysis of the digital economy}

The countries of the Organisation for Economic Cooperation and Development have developed a special system of indicators to measure the level of development of digital economies. This system characterises such indicators among the following categories: development of the high-tech sector of the economy, scientific development of investments, software development, expenses on education, and retention in the sphere of science and high technologies.

There are several criteria for analysing the digital economy:

- $\quad$ information (replacement of physical labor with information);

- $\quad$ spatial (development of data networks);

- $\quad$ economic (the growth of digital values);

- technological (growth of innovations in the field of information and communication technologies).

Complementary criteria are also possible.

The information criterion is closely related to the sphere of employment. It is mentioned in the works of D. Bell

[17] and C. Leadbeater [18], which consider the structure of employment. It is mentioned that the models of changes in socio-economic relations are due to the fact that a large number of people work in the digital economy. Statistics show that the proportion of people employed in data processing services is increasing every year, which proves the existence of the digital economy. The main problem with this approach is the complexity of profiling the staff involved in working with data. For example, the process of the formation of the digital economy may be considered equivalent to the process of the growth of specialists in computer technology and telecommunications, because the main task is data processing. But currently there is no method of counting the workers of the digital economy. There is also a rapidly growing number of workers in the related fields of law, trade, etc., who have a weak connection with the digital economy, but they find themselves in the same category through inevitable association. The spatial criterion is founded on the geographical principle. Special attention is paid to the creation of a global economic space. Data transmission is an important feature of modern society. At the moment, the spatial criterion raises many questions about the network, the volume and speed of transmission, which determine the transition to the digital economy.

The economic criterion is the growth of economic value in the creation, transmission, processing and storage of data. This activity is developing more rapidly in the economic sphere than in agriculture and industry, and this allows us to talk about the digital economy. In this case, the data becomes the object of economic relations. The main problem is that the evaluation of the performance methodology related to data processing is not sufficiently developed.

The technological criterion implies that the increase in technological innovation leads to the restructuring of socio-economic relations [19].

When considering different approaches, it becomes clear that there are no exact provisions on the issue of the optimal deployment and coordination of digital technologies. Many researchers rely on quantitative characteristics, and suggest that the digital economy is beginning to dominate. It should be understood that the increase in data flows will not be a purely quantitative factor and subject to statistical measurement. When calculating some economic data, it becomes clear that the qualitative characteristics of the subject are not appropriately considered. In this manner, it is as if digital data circulates in one isolated system and everything within is considered as a homogeneous mass, and the qualitative aspects remain out of sight. The questions of service quality, methods, process and management decisions is essential to the formation of the digital economy. Related aspects of the digital economy in Russia are shown in figure 5.

Figure 5. Aspects of digital economy development in Russia

\begin{tabular}{|c|c|}
\hline Personnel & $\begin{array}{l}\text { the Russian education } \\
\text { system has a high poten- } \\
\text { tial for training specialists } \\
\text { in the digital economy }\end{array}$ \\
\hline Infrastructure & $\begin{array}{l}\text { original organisational and } \\
\text { technological solutions } \\
\text { are necessary to create an } \\
\text { effective infrastructure for } \\
\text { the digital economy }\end{array}$ \\
\hline Efficiency & $\begin{array}{l}\text { the integration and devel- } \\
\text { opment of specific proj- } \\
\text { ects on the basis of the } \\
\text { modern principles of the } \\
\text { digital economy will create } \\
\text { a synergetic effect and } \\
\text { lead to the overall growth } \\
\text { of the Russian economy }\end{array}$ \\
\hline
\end{tabular}




\section{Conclusion}

Theorists of the digital economy conclude that the economy must undergo serious changes [12]:

1) Data are the main resource in the formation of the digital economy, and we need to understand their relative quality.

2) The peculiarity of the increase in data flows that adversely affect the digital economy must be carefully considered.

3) The ability to store data in high-speed and capacious devices (communication networks, cloud), means that the analysis of colossal amounts of data has become a limitation.

4) Digital technologies include a wide range of users who in the process of using services, can find certain shortcomings and continue development through feedback.

5) Fundamental technological changes interact to produce innovation.

The following conditions need to be implemented for the development of societies:

- the association of people for the production and translation of new knowledge should be developed as a priority matter;

- initiatives to increase communication and increase access to the exchange and transfer of knowledge should be fostered.

The transition to a new level of management of economic processes that allow for more accurate analysis of economic activity is possible through increasing data flows. New databases allow forecasting economic processes in corporations. Modern smartphones and the internet instantly allow you to create digital models of consumers and technological processes, which leads to resource savings. Increased use of digital devices has led to the emergence of 'big data'. As stated previously, working with such data is the foundation of the digital economy [20].

The digital economy provides new opportunities for communication and the exchange of experiences and ideas. Digital technologies play an important role in training and knowledge sharing and the implementation of ideas, in professional as well as in social spheres [2]. To complement this, the importance of the digital economy to corporations should be unambiguously emphasised and reinforced.

Risk analysis deserves particular attention. Underestimating the impact of risks on the transformation process prevents the creation of a full-fledged digital economy. Together with countries that actively implement and use digital technologies, there are territories that are cut off from global information communications. These regions are not able to easily switch to a digital type of functioning in their economic systems. Inequality is expressed in the poor functioning of institutions [12]. Consequently, geopolitical and technological contradictions between the leading countries become one of the main risk indicators from the point of view of ensuring national security issues directly related to technological risks.

\section{References}

1. Ritchie B., Brindley C. Risk management in the digital economy. In: Khosrow-Pour M., ed. Encyclopedia of information science and technology. $2^{\text {nd }}$ ed. Hershey, PA: IGI Global; 2009:3298-3305. DOI: 10.4018/978-1-60566-026-4.ch525

2. Chernyakova M.M. Socio-economic factors in the development of the digital economy. Nauka Krasnoyar'ya = Science of Krasnoyarsk. 2018;7(32):116-122. (In Russ.).

3. Chernyakov M.K., Chernyakova M.M., Razomasova E.A., Arutyunyan N.V. Innodiversification.

Konkurentosposobnost' $v$ global'nom mire: ekonomika, nauka, tekhnologii = Competitiveness in the Global World: Economics, Science, Technology. 2016;(6):283287. (In Russ.).

4. On approval of the program "Digital Economy of the Russian Federation". Order of the Government of the Russian Federation of 28.07.2017 N 1632-p. URL: http://www.consultant.ru/document/cons_doc_LAW _221756/2369d7266adb33244e178738f67f181600cac 9f2/ (In Russ.).

5. Kolodnaya G. Digital economy: features of development in Russia. Ekonomist. 2018;(4):63-69. (In Russ.).

6. Raisinghani M. Business intelligence in the digital economy: Opportunities, limitations and risks. Hershey, PA, London: Idea Group Publ.; 2004. 304 p.

7. Osipovich T.A., Chernyak M.K., Chernyakova M.M. On the issue of country risk assessment. In: Days of science - 2018. Proc. int. sci.-pract. conf. (Novosibirsk, 4-5 Apr. 2018). Pt. I. Novosibirsk: Siberian Univ. of Consumer Cooperatives; 2018:143-149. URL: http://www.sibupk.su/upload/ medialibrary/cc6/\%D0\%94\%D0\%BD\%D0\%B8\%20 \%D0\%BD\%D0\%B0\%D1\%83\%D0\%BA\%D0\%B8\%D0\%A7.\%201.pdf (In Russ.).

8. Chernyakov M.K., Chernyakova M.M. Classification of risks of digital economy. Finansovaya ekonomika = Financial Economy. 2018;(6):384-389. (In Russ.).

9. Yakovleva E.L. Electronic nomad as a new form of identification. Filosofiya $i$ kul'tura $=$ Philosophy and Culture. 2015;(11):1655-1664. DOI: 10.7256/19992793.2015.11.15689 (In Russ.).

10. Korchagin S.A., Polschykov B.P. Digital economy and transformation of public administration mechanisms: Risks and prospects for Russia. Svobodnaya mysl'. 2018;(1):22-36. (In Russ.). 
11. Shadrina T. Overtake without catching up. N. Kasperskaya: How can Russia preserve digital sovereignty. URL: https://rg.ru/2018/03/04/nataliakasperskaia-nelzia-dopustit-oborota-v-rf-chuzhihkriptovaliut.html (In Russ.).

12. Digital economy: Advantages and risks in the system approach. An opinion. 2017. URL: http://geo-politica. info/tsifrovaya-ekonomika-preimuschestva-i-riski-vsistemnom-podkhode-mnenie.html (In Russ.).

13. Shadrina T. Experts warned about the seven risks of the digital economy. 2018. URL: https:// rg.ru/2018/02/28/eksperty-predupredili-o-semiriskah-cifrovoj-ekonomiki.html (In Russ.).

14. Stojanović D. Digitalna ekonomija i transformacija poslovnih procesa - izazovi i rizici. Ekonomija: teorija i praksa. 2017;10(1):80-90. DOI:10.5937/etp1701080S

15. Surovtseva V.A., Kurbatova V.A., Chernyakov M.K. Assessment and management of competitive risks. Vestnik Evraziiskoi nauki = The Eurasian Scientific Journal. 2018;10(2):45. URL: https://esj.today/ PDF/41ECVN218.pdf (In Russ.).
16. Dyachkova N.F. Comparison of rating scales of Russian and foreign agencies: An impirical study for industrial and financial companies. Korporativnye finansy = Journal of Corporate Finance Research. 2018;16(2):35-52. (In Russ.).

17. Bell D. The coming of post-industrial society: A venture in social forecasting. New York: Basic Books; $1999.618 \mathrm{p}$.

18. Leadbeater C. Living on thin air: The new economy. New York: Viking Book Publ.; 1999. 256 p.

19. Semenov Yu.A. IT-economy in 2016 and 10 years later. Ekonomicheskie strategii = Economic Strategies. 2017;19(1):126-135. (In Russ.).

20. Popov E.V., Semyachkov K.A. Features of digital economy development management. Menedzhment $v$ Rossii i za rubezhom = Management in Russia and Abroad. 2017;(2):54-61. 